\title{
PERANAN KEPALA SEKOLAH SEBAGAI SUPERVISIOR DALAM MENINGKATKAN KUALITAS PEMBELAJARAN (Telaah Teortik)
}

\author{
${ }^{1}$ Rustam Hasim, ${ }^{2}$ Subhan Hayun \\ ${ }^{1}$ Program Studi Pendidikan Pancasila dan Kewarganegaraan, FKIP Universitas Khairun \\ ${ }^{2}$ Program Studi Pendidikan Guru Sekolah Dasar (PGSD) Universitas Pasifik Morotai
}

\begin{abstract}
Principal as a supervisor has important roles in learning and teaching process, and has educational standards and qualities. In performing his or her roles, principal always pays attention to human relations among teachers, employers and students. Supervision is an effort to help and service teachers to improve their teaching ability. Supervisor is not directly linked to students, since teachers manage students. Supervisor is not a directive task but more likely to be a consultative one (such as supporting, suggesting, and guiding). Method used in this research is descriptive qualitative method which illustrates and describes the roles of principal in improving the learning quality. The roles of principal as administrator and supervisor are the main object. Based on teacher competency, the ability of teachers shows a slight improvement. The improvement of teachers' ability is resulted from supervision ways and approaches at school in managing, supporting and guiding the elements of schools. Based on quality standard, the implementation of supervision is improved. This means that the assistance and the management of the supervisor of the principal, and supervision approaches implemented by the principal in his or her effort to increase and to develop teachers' competency in the process of learning and teaching show better qualities and progression.
\end{abstract}

Keywords: Supervision, Principal, and Teachers' Competency

\section{PENDAHULUAN}

Pendidikan merupakan usaha untuk membantu perkembangan potensi dan kemampuan anak agar bermanfaat bagi kepentingan hidupnya sebagai seorang individu dan sebagai anggoya masyarakat atau warga Negara. Pendidikan dapat terlaksana dengan baik apabila terdapat keterkaitan yang didaktis dan pendagogis dari seluruh komponen pendidikan baik sarana maupun prasarana.

Kepala sekolah sebagai supervisor mempunyai peranan yang sangat penting dalam proses belajar mengajar dan mempunyai mutu atau kualitas pendidikan. Berdasarkan dengan uraian di atas, maka tujuan pendidikan nasional yang digariskan dalm garis-garis besar haluan negara tahun 1988 bahwa "Pendidikan nasional berdasarkan pancasila, bertujuan untuk meningkatkan kualitas manusia yaitu manusia yang bertaqwa dan beriman terhadap tuhan yang maha esa, berbudi pekerti luhur, kepribadian, berdisiplin, bekerja keras, tangguh, bertanggung jawab, mandiri, cerdas, dan terampil serta sehat jasmani dan rohani. Pendidikan nasional 
juga harus mampu menumbuhkan dan memperdalam rasa cinta pada tanah air, mempertebal semangat kebangsaan, dan rasa kesetiakawanan sosial. Sejalan dengan itu maka dikembangkan iklim belajar dan mengajar yang sikap dan prilaku yang inovatif dan kreatif. Dengan demikian pendidikan nasional akan mampu mewujudkan manusia-manusia yang dapat membangun dirinya sendiri serta bersama-sama bertanggung jawab atas pembangunan bangsa."

Maju tidak pendidikan di suatu sekolah tergantung juga kepada kepala sekolah sebagai tenaga kependidikan, baik personal, sosial maupun professional harus benar-benar dipikirkan karena pada dasarnya kepala sekolah sebagai tenaga pendidikan disekolah menjadi contoh teladan bagi bawahannya serta kepada peserta didiknya dan sebagai ujung tombak keberhasilan pendidikan disekolah.

Di dalam proses belajar mengajar baik didalam sekolah maupun diluar sekolah yang dilaksanakan oleh seorang atau semua guru selalu dikontrol oleh kepala sekolah. Ini berarti bahwa peranan kepala sekolah sangat luas karena mencurahkan perhatian, tanggung jawab serta pengawasannya terhadap kelancaran proses belajar mengajar untuk meningkatkan mutu pendidikan.UU No. 2 Tahun 1989 tentang sistem pendidikan Nasional bahwa "Pendidikan nasional bertujuan untuk mencerdaskan kehidupan bangsa dan mengembangkan manusia Indonesia seutuhnya, yaitu manusia yang beriman dan bertaqwa terhadap tuhan yang maha esa, dan berbudi pekerti luhur, memiliki pengetahuan, ketrampilan kesehatan jasmani dan rohani, kepribadian yang mantap dan mandiri serta rasa tanggung jawab kemasyarakatan dan kebangsaan".

Dalam menjalankan supervisi pendidikan yakni kepala sekolah sebagai supervisor berusaha untuk dapat menolong guru dan mengembangkan kurikulum. Menyediakan fasilitas yang memungkinkan guru-guru dapat menambah dan mempertinggi pengetahuan serta membina rasa kekluargaan antara guru-guru dan pegawai sekolah sesuai dengan kondisi dan situasi setempat.

Sehubungan dengan uraian di atas, maka Tomkins dan Backley mengatakan bahwa "Kualitas penting bagi seorang supervisor adalah memiliki instuti yang baik, kerendahan hati, kerama tamahan, ketekunan sifat humor, kesabaran dan sebagainya adalah ciri-ciri yang terpenting karena supervise menyangkut hubungan antara orang-orang (Tomkin dan backley, 1984: 62).

Dari pendapat tersebut di atas nampak jelas bahwa, kepala sekolah dalam menjalankan tugasnya selalu memperhatikan hubungan kemanusiaan baik terhadap guru-guru, pegawai maupun anak didik. Dalam kaitannya dengan ini, M, Moh. Rifai MA (1987), mengatakan bahwa supervisi merupakan usaha untuk membantu dan melayani guru meningkatkan kemampuan keguruannya : supervisi tidak langsung diarahkan kepada peserta didik, tetapi kepada guru yang membina peserta didik tersebut : supervise tidak bersifat direktif (mengarahkan) tetapi lebih banyak bersifat konsultatif (memberikan dorongan, saran dan bimbingan).

Nana Sudjana (1991) mengemukakan bahwa supervisi adalah bantuan yang diberikan kepada semua gurudan staf sekolah untuk mengembangkan situasi 
belajar mengajar yan $\mathrm{g}$ lebih baik. Hakekat tugas-tugas pengawas untuk melaksanakan supervise yang efektif dengan cara demokratif dalam rangka meningkatkan kegiatan-kegiata professional disekolah, dan hubungan antar staf yang koperatif untuk sama-sama meningkatkan kemampuan masing-masing (Depdikbud, 1994). Sasaran utama supervisi adalah guru (tidak berarti bahwa staf yang lainnya tidak perlu disupervisi/dibina). Karena dipundak gurulah terletak tanggung jawab lebih besar terhadap upaya peningkatan proses belajar mengajar/ pembelajaran dan hasil belajar sehingga akan mencapai tingkat keefektifan yang diharapkan.

Sekolah menegah pertama (SMP), dasar sebagai organisasi pendidikan, memerlukan guru-guru dan tenaga pendidik lainnya mampu mejalankan tugas dengan baik. Dalam PP No. 28 tahun 1990, pasal 3 dijelaskan bahwa pendidikan dasar bertujuan untuk memberikan bekal kehidupan sebagai pribadi, anggota masyarakat, warga negaradan anggota umat manusia serta mempersiapkan peserta didik untuk mengikuti pendidikan menengah. Dari pernyataan tersebut berarti pendidikan dasar merupakan fandasi pada pendidikan pada jenjang-jenjang berikutnya.

Terlepas dari permasalahan apakah kepala sekolah sudah mampu atau belum dan melaksanakan tugas tersebut, karena jelas mereka memegang peranan yang amat penting sebagai salah satu factor penentu keberhasilan pendidikan dasar. Betapa pentingnya peranan itu bila dikaitkan dengan pernyataan yang mengatakan bahwa pembinaan guru, terutama bantuan yang terwujud bimbingan professional, yang dilakukan oleh pengawas dan dapat meningkatkan kemampuan guru dalam proses belajar mengajar. Disamping itu pembinaan guru juga dimaksudkan sebagai usaha terlaksanannya sistem kenaikan pangkat dalam jabatan fungsional guru (dalam hal ini dorongan untuk berprestasi memperoleh angka kredit).

Guru merupakan faktor yang sangat dominan dan paling penting dalam pendidikan formal pada umumnya karena bagi peserta didik, guru sering dijadikan tokoh teladan, bahkan menjadi tokoh identifikasi diri. Oleh sebab itu, guru seyogyanya memiliki perilaku dan kemampuan yang memadai untuk mengembangkan siswanya secara utuh. Kenyataan dilapangan menunjukan bahwa performance (unjuk kerja) guru didalam melaksanakan kegiatan belajar mengajar (KBM) sangat bervariasi dan kualifikasi keguruannya beraneka ragam.

Disisi lain banyak terdapat guru yang mengasuh dan mempertanggung jawabkan mata pelajaran yang tidak sesuai dengan wewenang dan kemampuan profesionalnya serta kemajuan dan perkembangan ilmu pengetahuan dan teknologi yang telah menuntut adanya penyesuaian dan perkembangan professional guru untuk dapat mengembangkan pendidikan disekolah, khususnya dalam ahli teknologi. Berdasarkan hal-hal di atas maka perlu ditingkatkan kemampuan professional para pengawas, kepala sekolah, guru dan tenaga pendidik lainnya, dalam upaya mengelolah pembelajaran para siswa secara baik/benar dan berhasil guna. 
Uraian di atas menunjukkan bahwa seorang guru senantiasa dituntut bergiat meningkatkan kemampuan pribadi dan profesional, guru-guru juga mengharapkan bantuan orang lain terutama kepala sekolah dan pengawas dalam bentuk supervisi. Pembinaan guru-guru terutama bantuan yang berwujud bimbingan professional yang dilakukan pengawas, kepala sekolah dan pegawas lainnya untuk meningkatkan profesi dan hasil pembelajaran. Berdasarkan latar belakang masalah tersebut maka pertanyaan yang aka diajukan dalam tulisan ini adalah bagaimana peranan kepala sekolah dalam meningkatkan kualitas pembelajaran.

\section{PEMBAHASAN}

\section{Pengertian Supervisi}

Kegiatan pengajaran ditujukan untuk peningkatan mutu guru yang dapat pula meningkatkan kegiatan belajar mengajar, supervisi merupakan suatu proses atau suatu rangkaian kegiatan yang berkaitan, berurutan dan menuju kesuatu tujuan tertentu. Untuk tidak salah mengartikan pengertian supervisi maka penulis mencoba mengemukakan beberapa pendapat sebagai berikut :

Menurut Nealey dan Evans mengatakan bahwa: the than supervision is used to describe those activities which are primarily and defetly concerned with studing and improving the contidition which surround the learning and growth of pupils and teacher. (Nealey dan Evans . Ngalim Purwanto, 1989 : 52). Sedangkan menurut Burton mengatakan bahwa: supervise on is and expert teacnical servise primarily aimed at study ing and inproving co-operatively all factor which affert child grouth and defelepment. (Burton dalam Ngalim Purwanto, 1989 : 53).

Menurut Suryo Subroto, bahwa supervisi adalah pembinaan yang diberikan kepada seluruh staf sekolah agar mereka dapat meningkatkan kemampuan untuk mengembangkan situasi belajar mengajar yang lebih baik (Suryo Subroto,1984 :117).

Dari beberapa pengertian supervisi yang telah dikemukakan di atas, maka secara implisit dapat dikemukakan bahwa supervisi sesuai dengan konsep di atas bertitik tolak dari pemikiran bahwa setiap guru dan kepala sekolah memiliki potensi untuk dikembangkan. Tegasnya kecakapan mengajar guru dan kecakapan memimpin dari kepala sekolah masih dapat dan ditingkatkan. Lebih-lebih dalam iklim kependidikan dewasa ini dimana pembaharuan-pembaharuan selalu terjadi.

Dalam pendidikan faktor manusia sangat menentukan. Guru dan kepala sekolah yang cakap disertai dengan kepemimpinan yang baik lebih menjamin mutu pendidikan dan tercapainyatujuan pendidikan itu sendiri. Atas dasar itu sehingga Pembinaan terhadap manusia yang berperan disekolah, tegasnya guru dan kepala sekolah sangat diperlukan dalam memegang posisi kunci dalam upaya peningkatan mutu pendididkan. 
Program pembinaan personel disekolah (guru dan kepala sekolah) dibidang pendidikan disebut supervise pendidikan. Perkataan supervise berasal dari bahasa inggris "supervision" yang terdiri dari dua perkataan yaitu super dan vision. Super berarti atas atau lebih, dan vision berarti melihat atau meninjau. Dengan demikian secara etimologi supervisi berarti melihat atau meninjau dari atas. Maksudnya peninjauan dari pihak atasan kepada bawahan atau kepada orang-orang yang memiliki kelebihan tertentu.

\section{Tujuan Supervisi Pendidikan}

Menurut H. Hadari Nawawi (1986) menyatakan bahwa tujuan supervisi adalah menilai kemampuan guru dan kepala sekolah sebagai pendidik dibidangnya masing-masing dalam rangka membantu mereka melakukan perbaikan-perbaikan serta peningkatan diri dan tugasnya bilamana diperlukan menunjukan kekurangan dan kelemahan mereka agar dapat di atasi dengan usaha sendiri. Dedi supriadi (1995) juga menjelaskan bahwa tujuan supervise adalah untuk membantu guru meningkatkan kemampuannya agar menjadi guru yang lebih baik. Selanjutnya M. Moh Rivai (1987) mengemukakan tujuan supervisi adalah untuk membantu guru agar dapat belajar bagaimana meningkatkan kemampuannya atau kapasitasnya sehingga murid-muridnya dapat mewujudkan tujuan belajar yang telah ditetapkan.

Dari pendapat-pendapat di atas, jelas bahwa tujuan supervisi adalah untuk mengembangkan situasi belajar mengajar yang lebih baik melalui uisaha peningkatan kemampuan professional guru. Adapun Tujuan supervisi pendidikan adalah:

a. Membantu guru agar lebih mengerti/ menyadari tujuan-tujuan pendidikan sekolah dan fungsi sekolah dalam usaha mencapai tujuan pendidikan itu.

Pendidikan bukan hanya melatih dan mengembangkan pengetahuan dan penalaran saja, namun pendidikan jauh lebih kompleks sifatnya dan mencakup pengembangan norma. Estetika moral, fisik sesuai dengan nilainilai yang dikehendaki dan dibutuhkan oleh masyarakat. Kita dapat menyederhanakan perumusan tujuan itu dengan mengatakan bahwa sekolah harus turut membantu, membina manusia seutuhnya dan memperhatikan perkembangan siswa dalam segala segi-seginya.

b. Membantu guru agar mereka lebih menyadari dan merti kebutuhan dan masalah-masalah yang dihadapi siswa, supaya dapat membantu siswanya itu lebih baik lagi.

c. Untuk melaksanakan kepemimpinan efektif dengan cara yang demokratis dalam rangka meningkatkan kegiatan-kegiatan professional disekolah, dan hubungan antara staf yang kooperatif untuk bersama-sama meningkatkan kemampuan masing-masing.

d. Menemuka kemampuan dan kelebihan tiap guru dan memanfaatkan serta mengembangkan kemampuan itu dengan memberikan tugas dan tanggung jawab yang sesuai dengan kemampuannya. 
e. Membantu guru meningkatkan kemampuan penampilannya didepan kelas.Kemampuan didepan kelas dapat kita namakan juga kemampuan mengajar yaitu kemampuan untuk membuat murid lebih giat belajar.

f. Membantu guru baru dalam masa orientasinya supaya cepat dapat menyesuaikan diri dengan tugasnya dan dapat mendayagunakan kemampuannya secara maksimal. Bantuan ini memberikan penjelasan mengenai tugas dan tanggung jawab yang akan dihadapinya.

g. Membantu guru menemukan kesulitan belajar murid-muridnya dan merencanakan tindakan perbaikannya. Aini dimaksudkan agar murid dapat belajar seefektif dan seefisien mungkin dengan hasil yang semaksimal.

h. Menghindari tuntutan-tuntutan guru yang diluar batas atau tidak wajar, baik tuntutan itu dating dari dalam sekolah maupun dari luar sekolah (masyarakat). Ini dimaksudkan untuk mendekatkan sekolah dengan masyarakat, untuk bertindak kedalam terhadap guru-gurunya dan bertindak keluar terhadap masyarakat. (M. Moh. Rifai. Administrasi dan Supervisi Pendidikan, 1982: 38).

\section{Fungsi dan Prinsip Supervisi pendidikan}

Sejalan dengan beberapa defenisi dan tujuan supervise yang telah diuraikan dimuka dapatlah dikatakan bahwa focus dari sasaran utama supervise adalah guru (tidak berarti bahwa staf lainnya tidak perlu disupervisi/ dibina) karena pada gurulah letak tanggung jawab yang paling besar terhadap upaya peningkatan proses belajar mengajar / pembelajaran dan hasil belajar. Kegiatan supervisi ditujukan kepada peningkatan mutu guru yang dapat meningkatkan pula kegiatan belajar mengajar dan dengan demikian meningkatkan mutu pendidikan disekolah.

Supervisi merupakan suatu proses, artinya suatu rangkaian kegiatan yang berkaitan dan berurutan dan menuju kesuatu tujuan tertentu. Kegiatan-kegiatan dalam prose situ sifatnya dan fungsinya bermacam-macam. Ada kegiatan yang sifatnya menilai, membimbing, mengkoordinasi dan sebagainya, dari kegiatan tertentu kita melihat supervise sebagai usaha untuk menilai, maka kita dapat katakana bahwa supervise mempunyai fungsi penilaian. Kegiatan lain dalam supervise memperlihatkan usahanya dalam mempengaruhi dan membimbing, maka asumsi kita supervise berfungsi sebagai kepemimpinan.

Untuk mendapatkan ganmbaran yang lebih jelas, maka di bawah ini penulis akan uraikan fungsi supervise yang tertentu saja ada hubungan dengan tujuan yang ingin dicapai. Menurut Ngalim Purwanto, dkk. dalam buku Administrasi Pendidikan, mengatakan bahwa fungsi-fungsi supervise pendidikan sangat perlu diketahui oleh para pemimpin pendidikan termauk kepala sekolah, adalah sebagai berikut:

a. Dalam Bidang kepemimpinan

Dalam bidang kepemimpinan antara lain; Menyusun rencana dan policy bersama, mengikut sertakan kelompok (guru-guru, pegawai) dalam berbagai 
kegiatan. Memberikan bantuan kepada anggota kelompok dalam menghadapi dan memecahkan persoalan-persoalan. Membangkitkan dan memupuk semangat kelompok, Mengikut sertakan semua anggota dalam memutuskan keputusankeputusan. Membagi-bagi dan mendelegasikan wewenang dan tanggung jawab pada anggota kelompok. Mempertinggi daya kreatif pada anggota kelompok dan menghilangkan rasa malu dan rasa rendah diri pada anggota kelompok, sehingga mereka berani mengemukakan pendapat demi kepentingan bersama.

b. Fungsinya dalam hubungan kemanusiaan

Fungsinya dalam hubungan kemanusiaan yaitu memaafkan kekeliruan ataupun kesalahan-kesalahan yang dialami untuk dijadikan pelajaran demi perbaikan selanjutnya, bagi diri sendiri maupun bagi anggota kelompoknya. Membantu mengatasi kekurangan ataupun kesulitab yang dialami anggota kelompok seperti dalam hal kemalasan, rendah diri, acu tak acuh, pesimistis dan sebagainya. Mengarahkan anggota kelompok pada sikap-sikap yang demokratis.

c. Dalam pembinaan proses kelompok

Dalam pembinaan proses kelompok antara lain mengenal pribadi anggota kelompok baik kel;emahanya maupun kemampuannya masing-masing. Menimbulkan dan sukap percaya-mempercayai antara sesame anggota maupu antara anggota dan pemimpin. Memupuk keadilan dan sikap tolong-menolong, memperbesar rasa tanggung jawab para anggota kelompok. Menguasai tehniktehnik memimpin rapat dan pertemuan-pertemuan lainnya.

d. Fungsinya dalam bidang Administrasi personil

Fungsinya dalam bidang administrasi personil ini antara lain memilih personil yang memenuhi syarat-syarat dan kecakapan yang diperlukan dalam suatu pekerjaan. Menetapkan personil pada tempat dan tugas yang sesuai dengan kecakapan.

e. Fungsinya dalam bidang evaluasi

Fungsi supervisi sebagai evaluasi dimana harus menguasai dan memahami tujuan-tujuan pendidikan secara khusus dan terperinci, memiliki norma-norma dan ukuran-ukuran yang akan digunakan sebagai kriteria penilaian, menguasai tehniktehnik pengumpulan data untuk memperoleh data yang lengkap, benar dan dapat diolah menurut norma-norma yang ada serta menafsirkan dan menyimpulkan hasilhasil penilaian hingga dapat gambaran tentang kemungkinan diadakan perbaikan (Ngalim purwanto, 1989: 63).

\section{Prinsip-prinsip supervisi pendidikan}

Yang perlu bagi seorang supervisor adalah prinsip-prinsip untuk dijadikan landasan, pegangan dan pedoman bagi tindakan dan kebijaksanaan yang akan diambilnya. Menurut M. Moh. Rifai dalam buku administrasi dan supervise pendidikan, mengatakan bahwa prinsip-prinsip supervise terdiri atas prinsip-prinsip positif dan prinsip-prinsip negative. Prinsip-prinsip positif adalah sebagai berikut: 
1. Supervisi harus konstruktif dan kreatif artinya ia harus menimbulkan kreatifitas guru yang disupervisi dan ia sendiri harus kreatif menemukan cara-cara yang sesuai dengan kebutuhan.

2. Supervisi harus lebih berdasarkan sumber kolektif dari kelompok dari pada usaha supervise sendiri artinya supervise tidak bersifat deminatif dan direktif yakni tidak mengharuskan dan mengarahkan berdasarkan keinginan dan pendapat supervisor.

3. Supervisi harus dapat mengembangkan segi-segi kelebihan pada yang dipimpin artinya membantu guru untuk meningkatkan kemampuan profesionalnya.

4. Supervisi harus memberikan perasaan aman kepada anggota-anggota kelompoknya artinya perasaan aman ini tidak saja aman lahir/fisik tetapi terutama perasaan aman psikis, misalnya tidak tertekan, tidak merasa dikejar-kejar tugas bebas untuk mengeluarkan pendapat dan sebagainya.

5. Supervisi harus progresif artinya harus berani melangkah maju, menerapkan inisiatif dan kreatifitasnya dan tidak terikat pada ketentuan-ketentuan rutin saja.

6. Supervisi harus didasarkan pada keadaan yang rill dan sebenarnya artinya bukan keadaan yang dikhayalkan tetapi situasi yang nyata, potensi manusia dan potensi material yang sebenarnya adanya.

7. Supervisi harus sederhana dan informal dalam pelaksanaan, artinya tindakan supervise bukan paksaan tetapi bantuan yang harus diterima dengan penuh kesadaran oleh yang dibantu, situasi harus wajar, tidak dibuat-buat supaya anggota-anggota merasa aman dan tidak kehilangan rasa percaya pada diri sendiri.

8. Supervisi harus objektif dan sanggup mengadakan Self-evaluation artinya supervisor yang ingin membantu orang lain berkembang, harus dapat pula mengembangkan dirinya sendiri (M, Moh. Rifai. Adminis dan Super. Pend. 1982: 55).

Prinsip-prinsip yang bersifat negative antara lain ;

9. Supervisi tidak boleh bersifat mendesak/direktif.

10. Supervisi tidak boleh didasarkan atas kekuasaan pangkat/kedudukan atau atas dasar kekuasaan pribadi.

11. Supervisi tidak boleh dilepaskan dari tujuan pendidikan dan pengajaran.

12. Supervisi tidak boleh mencari kesalahan-kesalahan dan kekurangan.

13. Supervisi tidak boleh terlalu banyak mengenai soal-soal yang mendetail mengenai cara-cara mengajar dan bahan pengajaran.

14. Supervisi tidak boleh terlalu cepat mengharapkan hasil dan tidak boleh cepat kecewa (M. Moh. Rifai, 1982: 55). 


\section{Profesionalisme guru}

Guru merupakan pendidik dan pengajar yang menyentuh kehidupan pribadi siswa. Oleh karena itu sering dijadikan tokoh teladan, bahkan menjadi tokoh identifikasi diri. Oleh karena itu guru seyogyanya memiliki prilaku yang memadai utuk dapat mengembangkan diri siswa secara utuh. Menurut Rochman Natawidjaya (1989), menjelaskan bahwa untuk melaksanakan tugas profesionalnya, guru itu perlu memahami dan menghayati wujud siswa sebagai manusia yang akan dibimbingnya. Disisi lain, guru harus pula memahami dan menghayati wujud anak lulusan sekolah sebagai gambaran hasil didikannya yang diharapkan oleh masyarakat sesuai dengan filsafat hidup dan nilai-nilai yang dianut oleh bangsa Indonesia.

Adapun wujud siswa tidaklah sama epanjang masa, perkembangan ilmu pengetahuan dan teknologi yang memberikan dampak terhadap nilai-nilai budaya masyarakat Indonesia sangat mempengaruhi gambaran siswa yang diharapkan pun akan sangat dipengaruhi oleh keadaan itu sehingga apabila kita merumuskan kemampuan yang diharapkan, kita perlu mengantisipasi perkembangan keadaan dan tuntutan masyarakat pada masa yang akan datang.

Sekolah merupakan suatu lembaga formal yang mempunyai tnggung jawab untuk terus mendidik siswanya. Untuk itu sekolah menyelenggarakan kegiatan belajar mengajar sebagai realisasi tujuan pendidikan yang telah ditetapkan. Adapun penanggung jawab kegiatan proses belajar mengajar didalam kelas adalah guru karena gurulah yang langsung memberikan kemungkinana bagi siswa agar terjadi proses belajar siswa yang efektif.

Sebagaimana yang telah dikemukakan oleh nana Sudjana bahwa kehadiran guru dalam proses belajar mengajar atau pengajaran masih tetap memegang peranan penting. Peranan guru dalam proses pengajaran belum dapat digantikan oleh mesin,radio, tape recorder dan computer yang paling modern sekalipun. Masih terlalu banyak unsure manusiawi seperti sikap. Sistem nilai, perasaan, motivasi, kebiasaan dan lain-lain sebagai hasil dari proses pengajaran.tidak dpat dicapai melalui alat-alat tersebut.

Hal ini menunjukan pentingnya mengajar sebagai upaya hal ini menunjukan pentingnya mengajar sebagai upaya membelajarkan siswa. Cece Wijaya dan A. Tbrani Rusyan (1991), mengemukakan bahwa mengajar adalah membimbing kegiatan siswa belajar. Adalah mengatur dan mengorganisir lingkunganyang ada disekitar siswa sehingga dapat mendorong dan menumbuhkan soiswa untuk melakukan kegiatan belajar.

Melihat rumusan mengajar di atas, maka dalam proses belajar mengajar masih terjadi interaksi antara guru dan siswa. Apabila membicarakan proses belajar mengajar, dapatlah kita membayangkan bahwa dalam proses tersebut terjadi komunikasi antara guru dan siswa, sebab guru menyampaikan pesan-pesan (bahan pengajaran) kepada siswa. Atas dasar itu, guru sebagai komonikator dala rangka 
mengembangkan pelajaran, perlu memiliki kemampuan dasar dalam proses belajar mengajar.

Dalam proses belajar mengajar terdapat bermacam-macam perbedaan. Perbedaan-perbedaan tersebut antara lain disebabkan oleh kemampuan guru dalam mengajar, pengetahuan yang dimilikinya dan latar belakang pendidikannya. $\mathrm{H}$. Moh. Surya (1994), mengemukakan bahwa pengetahuan guru, baik dalam subjek materi, mengenai siswa, maupun mengenai proses belajar mengajar secara keseluruhan menentukan hasil belajar siswa. Juga para siswa yang mengikuti pelajaran belum tentudapat menangkap apa yang diberikan oleh guru. Sering kali guru tidak memberikan respon terhadap tingkah laku siswa didalam kelas.

S. Nasution (1991) menjelaskan bahwa kalau siswa tidak memahami apa yang dikatakan oleh guru, taupun apabila guru tidak dapat berkomunikasi dengan siswa, maka besar kemungkinan siswa tidak dapat menguasai mata pelajaran yang diajarkan oleh guru. Bila hal ini terjadi pada siswa maka sedikit sekali kemungkinan siswa memperoleh prestasi yang diharapkan. Keberhasilan siswa dapat dipengaruhi oleh sendiri dan dari luar pihak siswa. Dar pihak siswa adalah bakat, motivasi belajar, ketekunan waktu dan kelengkapan sarana dirumah.Sedangkan dari luara pihak siswa misalnya kemampuan guru yang baik, kondisi dan disiplin disekolah serta dorongan dan perhatian orang tua.

Departemen pendidikan dan kebudayaan (1997), menguraikan bahwa kemampuan guru dalam proses belajar mengajar dapat dirasakan dan dipantau oleh siswa dalam bentuk-bentuk antara lain :

1. Siswa dapat mengikuti penyajian guru.

2. Penyajian bahan tidak terlalu cepat.

3. Contoh-contoh dan soal-soal pelatihan diberikan secara cukup.

4. Guru membantu siswa mengingat pelajaran-pelajaran yang pernah diperoloeh, guru mengerti serta mengenal masalah belajar siswa.

5. Guru berusaha menjawab pertanyaan siswa seandainya siswa belum mengerti.

6. Guru membahas soal-soal pelatihan (tes) yang dapat dipecahkan oleh siswa.

Berdasarkan uraian tentang kemampuan guru dalam proses belajar mengajar tersebut di atas, diharapkan supaya yang diharapkan oleh guru seperti langkahlangkah di atas dapat membantu siswa mengikuti proses belajar mengajar dengan baik.

Dalam proses penyajian ini tentu ada hal-hal yang harus diketahui oleh siswa sebagai pengetahuan sikap yang dapat menunjang proses belajarnya. Sering ditentukan bahwa pengetahuan sikap sebagai prasyarat itu sudah mulai mamudar atau terlupakan sama sekali oleh siswa.cara mengatasinya adalah guru sekali-kali menyalingi pertanyaan-pertanyaan yang menguingatkan siswa terhadap bagianbagian itu, dan kalau perlu memberitahukan apa yang seharusnya diketahui. Hal ini berarti guru harus menyadari bahwa apa yang telah diajarkan sebagai memudar akan hilang sama sekali. Dalam hal ini dijelaskan oleh Hasibuan (1993), bahwa 
mengajar didepan kelas merupakan perwujudan interaksi dalam proses komunikasi. Guru sebagai pemegang kunci sangat menentukan keberhasilan belajar.

Bertitik tolak dari pandangan atau pendapat tersebut, maka semakin jelaslah bahwa faktor kemampuan sangat penting dimiliki oleh setiap guru dalam proses belajar mengajar. Semakin tinggi kemampuan guru dalam proseses melaksanakan proses belajar mengajar, diduga semakin tinggi pula prestasi belajar yang dicapai.

\section{SIMPULAN}

Berdasarkan uraian sebelumnya, maka dapatlah kesimpulan bahwa, sebagai supervisior pendidikan disekolah,pengawas menghadapi berbagai problem. Salah satu problem yang menuntut perbaikan pengawas adalah masalah kemampuan guru didalam melaksanakan kegiatan belajar mengajar (KBM). Salah satu gambaran tugas-tugas pengawas sebagai supervisior adalah kemampuan untuk menghadapi masalah-masalah yang dihadapi guru dalam melaksanakan kegiatan belajar mengajar. Dalam kaitannya dengan ini, bahwa supervisi merupakan usaha untuk membantu dan melayani guru meningkatkan kemampuan keguruannya : supervise tidak langsung diarahkan kepada peserta didik, tetapi kepada guru yang membina peserta didik tersebut : supervise tidak bersifat direktif (mengarahkan) tetapi lebih banyak bersifat konsultatif (memberikan dorongan, saran dan bimbingan).

Berdasarkan pokok pikiran di atas dapatlah dikatakan bahwa sebagai supervisior,pengawas harus dapat melaksanakan tugasnya dengan baik agar dapat membantu guru dalam meningkatkan kemampuan kegiatan belajar mengajar. Dengan demikian pengawas dalam melaksanakan supervise akan terwujud yaitu agar guru lebih mengerti/menyadari tujuan pendidikan disekolah, dan fungsi sekolah dalam usaha mencapai tujuan pendidikan serta dapat melaksanakan tugasnya dengan lebih baik.

Perhatian terhadap guru dewasa ini semakin lama semakin meningkat, usaha-usaha positif dan konstruktif untuk memperbaiki lembaga pendidikan tenaga kependidikan guna meningkatkan kualitas para guru diindonesia dilakukan secara sistematis dan berencana berdasarkan suatu konsepsi pendidikan guru mengandung fungsi yang sangat penting dalam rangka mempersiapkan generasi muda yang lebih baik. Usaha-usaha tersebut harus dimulai dari sekolah sebagai suatu lembaga pendidikan formal, perana guru sangat penting.

Dengan demikian secara kualitas kemampuan guru-guru dalam proses belajar mengajar semakin baik. Semakin baiknya kemampuan belajar guru-guru tidak terlepas dari pengaruh perilaku supervisi kepala sekolah di sekolah akan diikuti pula dengan semakin baiknya kemampuan mengajar guru-guru. 


\section{DAFTAR RUJUKAN}

Ametumbun, N.A. (1975). Supervisi pendidikan bagi Para Pembina Kepala Sekolah dan Guru-guru. Bandung : Karya Remaja.

Anonimous. (1993). Garis-garis Besar Haluan Negara. Surabaya: Bina Pustaka Tama.

Anonimous, (1998). Sistem Pendidikan nasional. Semarang: Aneka Ilmu.

Bafadel, Ibrahim. (1993). Supervisi Pengajaran suatu Tinjauan Praktis. Surabaya: Usaha Nasional.

Cece Wijaya. (1991). Kemampuan dasar Guru Dalam Proses Belajar mengajar. Bandung: Remaja Rosdakarya.

Depdikbud. (1987). Pedoman Proses Belajar Mengajar SD. Jakarta: Depdikbud.

Dedi Suryadi. (1995). Pedoman Supervisi Untuk Guru Sekolah Dasar. Jakarta: CV. Rajawali.

A. Achmad Djazuli. (1995). Supervisi Pendidikan Untuk Pendidikan Dasar. Jakarta: Dirjen Pendidikan.

H. Hadari Nawawi. (1986). Petunjuk Pelaksanaan Supervisi. Bandung : Remaja Rosdakarya.

H. Moh. Surya. (1986). Kemampuan Guru Dalam Proses Belajar Mengajar. Jakarta : PT Grasindo.

Hasibuan. (1993). Menjadi Guru Profesional. Bandung: Remaja rosdakarya.

M, Moh. Rivai. (1987). Guru Dalam Proses Belajar Mengajar. Bandung: Remaja Rosdakarya.

Mawawi, H. (1986). Administrasi pendidikan . Jakarta: Gunung Agung.

Murtain, H. (1986). Supervisi Pengajaran (Teori dan Praktek). Jakarta: PT. Grasindo.

Sanapiah Faisal. (1982). Metodologi Penelitian Pendidikan. Surabaya: Usaha Nasional.

R. Mardilis. (1990). Metodologi Penelitian Suatu Pendekatan Proposal. Jakarta : PT. melton Putra.

Pidart, M. (1986). Pemikiran tentang Supervisi pendidikan, Jakarta: Sarana Press.

Peraturan Pemerintah No. 28 tahun 1990. Pendidikan dasar. Jakarta: Armas Duta Jaya. 